\title{
12 \\ An FTA with the EU: What Could Be Gained? ${ }^{1}$
}

\author{
Bruce Gosper
}

\section{Too big to ignore}

When considering international economic policy, the European Union (EU) is simply too big to ignore. In 2014, the 28 members of the EU had a combined US dollar gross domestic product (GDP) of US $\$ 18.4$ trillion, making it the world's largest economy. On a purchasing power parity (PPP) basis, which adjusts for differences in spending power, the EU was again the world's largest economy in 2014, with a GDP of almost PPP $\$ 18.5$ trillion. ${ }^{2}$

Despite ongoing economic strains within the Eurozone, the EU is also an international trade and investment superpower. In 2013, for example, it was the world's largest exporter of merchandise goods, with extra-EU exports worth US $\$ 2,307$ billion, or around 15 per cent of the global total, and the world's second-largest importer of merchandise goods, with US $\$ 2,235$ billion of imports, also around 15 per cent of the world total. ${ }^{3}$

\footnotetext{
1 The case addressed here is based on the economic and commercial benefits of an agreement rather than other issues.

2 GDP data are from the International Monetary Fund (IMF) (2015b).

3 Data for merchandise and commercial services trade are from the World Trade Organization (WTO) (2014). Note that the reported numbers are for world trade excluding intra-EU trade. This is appropriate if we are treating the EU as a single economic area, just as we do not count (say) trade between Australian states in the international figures.
} 
The EU is also the world's largest exporter and importer of commercial services. Its extra-EU exports totalled US $\$ 891$ billion, which was almost one-quarter of the global total in 2013, while its imports were US\$668 billion, or almost one-fifth of the world's overall import bill.

In 2013, the EU was the source of US $\$ 250$ billion of foreign direct investment (FDI) outflows, behind only the United States of America (USA). In the same year, the EU received US $\$ 246$ billion of FDI inflows, making it the world's largest recipient (UNCTAD 2014).

The sheer economic heft of the EU makes it appear rather odd to many observers that the EU is the one major trading partner with which Australia does not have a free trade agreement (FTA) or even one currently under negotiation. In fact, as Mike Adams, Nicolas Brown and Ron Wickes point out in Trading Nation (2013), 'Australia and the European Union have purposely looked past each other in the rush for FTAs'.

This situation prevails despite the fact that, over time, there have been several calls on the Australian side for a deal with the EU. The 2008 Mortimer Review, for example, noted that the EU was 'the only major trading partner with which Australia is not negotiating or considering negotiating an FTA' and went on to propose (in recommendation 6.7) that the then government should consider the merits of negotiating a bilateral FTA with the EU, including the possibility of an agreement focused only on services and related investment, which it thought could deliver 'considerable benefits' (Mortimer \& Edwards 2008). A more comprehensive FTA would of course deliver even greater benefits for both sides and beyond.

\section{Why don't we already have an FTA with the EU?}

So, why don't we have a deal already? Adams, Brown and Wickes (2013) suggest several reasons as to why an agreement has so far failed to materialise. From an Australian perspective, these include Australia's perfectly sensible focus on the large-scale opportunities offered by the Asia-Pacific region; the absence of any compelling problems in the bilateral trade and investment relationship that require substantial policy intervention (aside from agriculture, of course); the fact that market access is already relatively easy due to generally low tariffs in both 
economies (an observation subject to the same qualification); and the presence of existing agreements already aimed at protecting investment and intellectual property. For example, the EU-Australia Partnership Framework, which was signed in 2008, included the objective of cooperation on mutual recognition approaches to facilitating trade in industrial goods (Rollo 2011).

The same authors also note that big and long-standing differences between Canberra and Brussels over agricultural policy may also have 'drained away the reserves of energy needed by trade negotiators and political leaders to seriously contemplate another big FTA'. Certainly, as Philomena Murray and M. Bruna Zolin (2012) point out, there can be little doubt that 'one single focus of intense conflict and strong emotions in Australia-EU relations has eclipsed all other aspects of the relationship over many decades ... the EU's agricultural policy and, especially, agri-food trade'.

Despite the past difficulties for the bilateral relationship posed by agriculture, and despite their own list of reasons as to why no FTA with the EU has yet been forthcoming, however, Adams, Brown and Wickes still conclude that there is a case for 'putting historical baggage to one side and taking a fresh look' at the issue.

That's a perspective that makes a great deal of sense, especially given that, under current circumstances, an FTA with the EU has the potential to deliver several important strategic and productive benefits to both Australia and the EU. This is most significant, perhaps, in key areas that foster the innovation both Australia and the EU need to drive future growth and respond to critical challenges, such as the impact of disruptive technologies, ageing and development of an appropriately skilled, mobile and competitive Australian labour market.

This chapter will concentrate on the arguments for, and benefits to, Australia from negotiating a comprehensive FTA with the EU. But there are also important benefits to the EU; for example, in better leveraging our deep integration with Asia and key areas of strength in financial services (e.g. superannuation and public-private partnerships in infrastructure financing) and in some areas of medical research and technology (e.g. neuroscience, cancer research and treatment), to name a few. 


\section{It's logical to look to a major trade and investment partner}

A logical and indeed obvious place to look for prospective negotiating partners is the group of countries that comprise our major trade and investment partners. On this basis, the $\mathrm{EU}$ is a standout contender, particularly with respect to trade in services and foreign investment.

In 2014 the value of Australia's total trade in goods and services with the EU was about $\mathrm{A} \$ 84$ billion, around 12.6 per cent of our total trade in goods and services that year. That made the EU our second-largest trading partner in 2013-14, behind only China (which had a 24 per cent share) (DFAT 2014). By market share, in 2013-14 the EU was Australia's fourth-largest export market overall, our fourth-largest export market for goods and our largest export market for services. The EU was also the most important source of all Australian imports, our second-largest source of goods imports and our largest source of services imports (DFAT 2014).

One interesting example of the bilateral trading relationship is provided by the case of Australian Scientific Instruments, a Canberrabased company that is owned by The Australian National University. In 2012, the company finalised a multimillion dollar contract for the supply of the world-leading Sensitive High Resolution Ion Micro Probe (or SHRIMP) to the Polish National Geological Institute. This equipment allows extremely accurate data to be collected from geological samples and provides insight into geological structures, with applications for the mining, oil and gas sectors. The Austrade post in Warsaw provided a supporting role to Australian Scientific Instruments in this process (Austrade 2012).

It's probably also worth noting at this point that the large trade flows described above take place against the backdrop of what is already a relatively liberal trade policy environment. According to the World Trade Organization (WTO), in 2013 the simple average most-favourednation (MFN) applied tariff in the EU was 5.5 per cent, compared to 2.7 per cent in Australia. On a trade-weighted basis, the EU average tariff in 2013 was just 2.6 per cent, compared to 3.9 per cent in Australia in $2012 .^{4}$

4 Sourced from WTO tariff profiles at stat.wto.org/TariffProfile/WSDBTariffPFHome.aspx?Languag $\mathrm{e}=\mathrm{E}$. 
There is, however, an important sectoral element to this story: the EU has an average MFN applied tariff of 13.2 per cent applying to the agricultural sector compared to a rate of just 4.2 per cent applying to the non-agricultural sector, as Table 1 shows. For Australia, the corresponding levels of protection in 2013 were 1.2 per cent and 3 per cent. On a tradeweighted basis, the average tariff applied to agriculture by the EU in 2013 was 8.4 per cent and 2.2 per cent for non-agriculture. In the case of Australia the corresponding figures were 2.6 per cent and 4 per cent.

Table 1. MFN applied tariffs in the European Union and Australia, 2013

\begin{tabular}{|l|r|r|}
\hline & European Union & Australia \\
\hline Average applied tariffs & 5.5 & 2.7 \\
\hline Overall & 13.2 & 1.2 \\
\hline Agricultural sector & 4.2 & 3.0 \\
\hline Non-agricultural sector & 2.6 & 3.9 \\
\hline Trade-weighted applied tariffs & 8.4 & 2.6 \\
\hline Overall & 2.2 & 4.0 \\
\hline Agricultural sector & & \\
\hline Non-agricultural sector &
\end{tabular}

Source: WTO 2015.

Then, of course, there is the fact that not only is the EU a major trading partner for Australia, but it is similarly an extremely important source of, and destination for, foreign investment.

The EU is Australia's largest foreign investor. The total stock of EU investment in Australia as of 31 December 2014 was A $\$ 959$ billion, 34 per cent of total foreign investment. Of that, A $\$ 170$ billion was FDI, 25 per cent of Australias total inward FDI. ${ }^{5}$

Recent inward investment stories include the following: in 2014, the Acciona-led Transcity Consortium received the Project of the Year Award from Infrastructure Partnerships Australia for Legacy Way, a A $\$ 1.5$ billion project to design, construct, maintain and operate a twin tunnel roadway in Brisbane; Nestle Australia expanded its operations in Australia by investing in a state-of-the-art medical nutrition facility for the company's health sciences business; and German technology company SAP recently established a data centre in Sydney (Austrade 2013). 
The EU is also the second-largest destination for Australian investment overseas in general and for FDI in particular. In 2014, the stock of Australian investment in the EU was $\mathrm{A} \$ 529.2$ billion, or about 28 per cent of the total stock of our outward investment. Of that total, about $A \$ 83.5$ billion was FDI, which was about 15 per cent of total outward FDI.

In summary, then, the scale of the bilateral relationship suggests that the potential pay-offs from an FTA would likely be significant. Moreover, given the relative importance of services trade and foreign investment, there are good grounds for believing that the kind of behind-the-border measures that modern FTAs address would be of particular benefit in encouraging additional economic flows between the two economies.

\section{An EU deal is the obvious missing element in Australia's list of FTAs}

The case for looking to the EU as a negotiating partner that is implied by the current depth of the bilateral economic relationship is further reinforced by taking a look at our current line-up of FTAs in order to identify any obvious gaps.

One way to approach this is to start with Australia's top 10 trading partners for goods and services. In 2013-14, these were (in descending order): China, EU, Japan, USA, Korea, Singapore, New Zealand, Malaysia, Thailand and Indonesia. Together, these 10 economies accounted for 77 per cent of total Australian trade (DFAT n.d.). ${ }^{6}$ Of this group of 10, Australia already has FTAs covering all of them except the EU. ${ }^{7}$ Adams, Brown and Wickes (2013) describe the EU as the 'biggest single missing jigsaw piece' in our current network of FTAs.

Table 2. Australia's bilateral trade in goods and services by top 10 partners, 2013-14

\begin{tabular}{|l|l|r|r|}
\hline Rank & Country & Value $(\mathrm{mln} A \$)$ & \% share of total \\
\hline 1 & China & 159,643 & 23.9 \\
\hline 2 & European Union & 83,379 & 12.5 \\
\hline 3 & Japan & 72,173 & 10.8 \\
\hline 4 & United States of America & 58,196 & 8.7 \\
\hline
\end{tabular}

6 If ASEAN is included as a group, the EU rank drops to three.

7 Indonesia is the only country in the top 10 without a direct FTA, but is covered in the ASEANAustralia-New Zealand Free Trade Agreement (AANZFTA). 
12. AN FTA WITH THE EU

\begin{tabular}{|l|l|r|r|}
\hline Rank & Country & Value $(\mathrm{mln}$ A\$) & \% share of total \\
\hline 5 & Republic of Korea & 34,589 & 5.2 \\
\hline 6 & Singapore & 29,510 & 4.4 \\
\hline 7 & New Zealand & 22,689 & 3.4 \\
\hline 8 & Malaysia & 19,887 & 3 \\
\hline 9 & Thailand & 18,837 & 2.8 \\
\hline 10 & Indonesia & 15,970 & 2.4 \\
\hline Total & & 514,873 & 77.1 \\
\hline
\end{tabular}

Source: DFAT 2014.

We get a similar message if we look at our leading investment relationships. So, for example, if we examine the stock of FDI as of end 2012, the top 10 source economies for inward FDI were (in descending order): EU, USA, Japan, China, Singapore, Canada, Switzerland, United Arab Emirates, Hong Kong and Malaysia. The corresponding top 10 destinations for Australian FDI were (again in order): USA, EU, New Zealand, Singapore, China, Malaysia, Indonesia, Hong Kong, Bermuda and India.

The EU stands out as a major bilateral investment partner with which Australia does not have an FTA either in place or under negotiation.

Table 3. Foreign direct investment flows into Australia by top 10 sources, 2014

\begin{tabular}{|l|l|r|r|}
\hline Rank & Country & Value (bln A\$) & \% share of total \\
\hline 1 & European Union & 169.6 & 24.6 \\
\hline 2 & United States of America & 163.4 & 23.7 \\
\hline 3 & Japan & 66.1 & 9.6 \\
\hline 4 & China & 30.0 & 4.4 \\
\hline 5 & Singapore & 28.0 & 4.1 \\
\hline 6 & Canada & 23.6 & 3.4 \\
\hline 7 & Switzerland & 19.0 & 2.8 \\
\hline 8 & United Arab Emirates & 14.6 & 2.1 \\
\hline 9 & Hong Kong & 11.5 & 1.7 \\
\hline 10 & Malaysia & 9.6 & 1.4 \\
\hline Total & & 535.4 & 77.8 \\
\hline
\end{tabular}

Source: ABS 2015. 
Table 4. Foreign direct investment flows from Australia by top 10 destinations, 2014

\begin{tabular}{|l|l|r|r|}
\hline Rank & Country & Value $(\mathrm{mln}$ A\$) & \% share of total \\
\hline 1 & United States of America & 136.2 & 25.2 \\
\hline 2 & European Union & 83.5 & 15.4 \\
\hline 3 & New Zealand & 61.6 & 11.4 \\
\hline 4 & Singapore & 13.1 & 2.4 \\
\hline 5 & China & 12.1 & 2.2 \\
\hline 6 & Malaysia & 6.0 & 1.1 \\
\hline 7 & Indonesia & 5.3 & 1.0 \\
\hline 8 & Hong Kong & 5.1 & 0.9 \\
\hline 9 & Bermuda & 3.6 & 0.7 \\
\hline 10 & India & 1.6 & 0.3 \\
\hline Total & & 328.1 & 60.7 \\
\hline
\end{tabular}

Source: ABS 2015.

\section{Agriculture is no longer the deal breaker that it used to be-the relationship is more diverse and sensitivities have modified}

To the compelling logic provided by the opportunity to plug in a critical missing piece in Australia's existing network of FTAs can be added the fact that agriculture need no longer serve as an automatic deal breaker in negotiations with the EU. As Don Kenyon and Pierre van de Eng (2014b) pointed out, in large part this is because a series of internal EU reforms have, over time, removed some of the serious market distortions that have been generated in the past by the EU's program of export subsidies. ${ }^{8}$

Granted, this does not mean that there are no significant issues remaining with regard to agricultural trade. The relatively high level of EU tariffs on agricultural products was noted above and the EU continues to retain significant levels of protection overall against agricultural imports that serve as a serious impediment to Australian exporters. But there are signs that the EU might be prepared to negotiate increased market access to its

8 Beginning with the initial common agricultural policy (CAP) reform package of 1992, the old regime of high support prices to EU farmers has gradually been replaced with direct income support (Kenyon \& van der Eng 2014b). 
valuable internal market for Australian farmers through the mechanism of expanded tariff quotas (TQs), with potentially significant gains in beef, grains, sugar, dairy and lamb. I say this from the perspective of being closely involved with the Commission in Doha Round discussions on market access during the last push for an agreement on the full agriculture agenda, in 2008.

At that time Australia was able to see the shape of what it might secure, albeit not easily, through implementation by the EU of Doha's proposed approach to agricultural market access. It was a discussion centred on what commercially meaningful concessions Australia might extract in return for some margin of manoeuvre for the Commission on the most sensitive areas of EU agriculture. In recent years, there has been strong cooperation between Australia and the EU on matters such as the AntiCounterfeiting Trade Agreement and the Trade in Services Agreement (TiSA). Indeed, in the area of services trade liberalisation in the WTO, the EU and Australia have been the most like-minded collaborators not only on matters like domestic regulation but also on the need to address equity caps and bind current practice and market opening.

Australian agriculture has substantial interests in better access to the EU market, and this would need to be a part of any negotiations Australia entered into. But after decades of unsuccessfully pushing at the door, many in the sector are reluctant to talk about what they might gain until they see a real negotiation engaged. And, of course, it shouldn't be assumed that we can predict which agricultural products might do well in a more open environment.

\section{There is ample scope for a substantive negotiating agenda}

What sort of issues can we expect to arise in a negotiation between the EU and Australia? One guide can be found in our respective submissions to WTO Trade Policy Reviews. In their 2015 review of Australia's trade policy, the EU commended the openness and transparency of Australia's trade regime, its commitment to multilateralism, and its strengthening of intellectual property laws. The EU noted the cooperation with Australia on the Anti-Counterfeiting Trade Agreement. On a less positive note, the EU urged continuing regulatory reform and for Australia to join the Agreement on Government Procurement (GPA), encouraged Australia 
to remove the luxury car tax, and highlighted the need for aligning of Australia's sanitary and phytosanitary measures with international standards.

For its part, in its comments to the 2013 trade policy review of the EU, Australia commended the EU's strong commitment to the multilateral system and in work with Australia on the TiSA. Australia noted recent reforms to the common agricultural policy (CAP), but said some coupled payments were increasing, and urged the EU to cease use of export subsidies and increase market access. Australia asked that the EU clarify third-country access to the government procurement market, commended efforts to harmonise the internal market but asked for more consistent application, and raised concerns about technical regulations restricting the processing of products imported from outside the EU.

This might give some sense of what an agenda might look like. Both Australia and the EU have made strong liberalising commitments in tariff elimination in respect of manufactured goods. Agriculture would be a substantial element, where Australia would push new access for items such as lamb, dairy, beef, wine and seafood. Perhaps a priority would be an update of the 1995 'Andriessen Assurance', with the EU undertaking not to supply subsidised beef in specified markets in Asia and the Pacific. And perhaps the EU would ask Australia to remove our single remaining agricultural TQ on its high-value cheeses. A negative list services agreement would be a priority for both.

Similarly, a substantial investment agreement would be fundamental given the nature of our economic relationship. Both Australia and the $\mathrm{EU}$ are committed to strong standards of intellectual property protection, and no doubt the EU would look for some recognition of its geographical indications interests, as would Australia of its interests in the continuing use of generic names. Australia has begun to articulate its own agenda on the protection of common names in world trade, and would value the opportunity to engage with the EU on this issue. Government procurement is seen by both as a key issue. Both Australia and the EU would bring sanitary and phytosanitary and technical barriers to trade issues to the table in a negotiation. Prima facie, this is a substantial agenda and with plenty of potential to enhance the overall relationship. 


\section{The alternative, multilateral route continues to look underwhelming ...}

If we could rely on the multilateral trading system to deliver a new, broadbased international trade agreement, then targeting a separate FTA with the EU might be a questionable use of limited negotiating resources. Unfortunately, for the moment the multilateral option continues to look incapable of delivering the kind of deep economic integration that a successful FTA might be able to provide with a sharp focus on lowering non-tariff barriers (NTBs).

The most compelling piece of evidence for this proposition is the low prospects for the original ambitions for the Doha Round; ambitions that anyway fell far short of the kind of 'deep integration' agenda now pursued in modern FTAs. The replacement of those original Doha goals with an even more modest agenda, based around the worthy but limited objective of trade facilitation, has subsequently confirmed the difficulties at the multilateral level. More generally, the repeated failure of the WTO ever since the debacle surrounding the so-called Singapore Issues (at least, ex-trade facilitation) of 1996 to meet the current appetite of the developed world for the kind of behind-the-border measures involving agreements on standards and regulation, investment, intellectual property, government procurement, competition policy and so on that are of increasing salience in today's global economy suggests that the appetite for deal-making outside the WTO will only persist.

Australia remains firmly committed to the multilateral system and to the benefits of a multilateral round. The decision to eliminate export subsidies on agriculture taken at the 10th WTO ministerial meeting in Nairobi in late December 2015 demonstrates how essential the multilateral system is in achieving such important systemic changes. Of course, multilateral negotiations are needed to address domestic agricultural subsidies. It should be clear that this is a subject that cannot be dealt with, certainly in any substantial way, in an FTA. Australia is also mindful of its commitments in FTAs as a way to continue to progress liberalisation, including through inbuilt agendas, to ensure our efforts are not counter to, but support, our efforts to advance a strong multilateral rules-based system. 


\section{The global environment remains challenging ...}

The limited outlook for the prospects for additional multilateral trade liberalisation is accompanied by a moderate outlook for global growth. According to the International Monetary Fund's (IMF) World Economic Outlook, for example, in real terms world economic growth is slowing. Projected rates are significantly below the average growth rates before the global financial crisis hit in 2008, and private investment is yet to recover (IMF 2015a).

Subdued global growth has contributed to subdued international trade. In the same forecast, for example, the IMF estimates that the volume of world trade in goods and services will expand in 2015 by 3.7 per cent and 2016 by 4.7 per cent, at rates just above those of world GDP. That compares to annual trend growth in trade volumes that was running at more than 7 per cent before the crisis.

Moreover, while international trade has certainly not suffered from the kind of mass relapse into protectionism that some pessimists feared might be triggered by the global financial crisis and the high unemployment that followed, nevertheless there are some troubling signs of advances in so-called murky protectionism. According to the 16th Global Trade Alert report of the London-based Centre for Economic Policy Research, for example, between the first quarter of 2012 and the third quarter of 2014 , the number of new protectionist measures implemented not only increased again, but in 2013 more new protectionist measures were imposed than in the crisis year of 2009 (Evenett 2014). More recently, the WTO's latest assessment judged that 'G-20 economies between midOctober 2014 and mid-May 2015 implemented fewer trade-restrictive measures per month than at any time since 2013'. However, the same report went on to caution that the:

longer term trend remains one of concern with the overall stock of traderestrictive measures introduced by G-20 economies since 2008 continuing to rise. Of the 1,360 restrictions recorded by this exercise since 2008, less than a quarter have been eliminated, leaving the total number of restrictive measures still in place at 1,031. Therefore, despite the G-20 pledge to roll back any new protectionist measures, the stock of these measures has risen by over 7\% since the last report. (WTO, OECD \& UNCTAD 2015) ${ }^{9}$

9 Note that the WTO coverage of protectionist measures is more restrictive than the approach taken by the Global Trade Alert reports. 


\section{And the world (including the EU) is moving on}

With the multilateral system failing to deliver the kind of deep integration that is now a priority for policy makers and businesses alike, many leading trading nations have sought alternative approaches, including FTAs, regional agreements and most recently the so-called mega-regional deals embodied in the Trans-Pacific Partnership (TPP) and Transatlantic Trade and Investment Partnership (TTIP). In recent years, the prevailing weak global economic environment has almost certainly helped to further reinforce this trend, offering as it does the prospect of a new impetus for growth and moreover one that may be particularly attractive to fiscally constrained governments.

In the case of the EU, the initial shift in emphasis in trade policy can be traced back to at least 2006, when the then EU Trade Commissioner was given a mandate to launch a new strategy for a 'Global Europe'. This mandate was then extended and deepened in 2010 as part of the Europe 2020 strategy. The result has been an official approach that has focused on signing deep and comprehensive FTAs with attractive trading partners, with the aim of not only securing improved commercial opportunities for European businesses, but also of using the EU's weight to shape the global trade and investment policy environment (Deutsch 2012).

The EU successfully concluded its first agreement under this new approach in 2010 in the form of an agreement with Korea and has also concluded an agreement with Singapore and Vietnam. Elsewhere in the region, the EU has negotiations underway with India (since 2007), Malaysia (since 2010, but paused since 2012) and Thailand (launched in May 2015). It also commenced negotiations with Japan in April 2013. And then there is the giant of all bilateral trade negotiations the TTIP. From an Australian perspective, the fact that the EU is now negotiating with many of our key regional trading partners as well as with the USA adds to the logic of pursuing our own FTA negotiations with Brussels.

Finally in this context, another recently concluded EU agreement, the Comprehensive Economic and Trade Agreement (CETA) with Canada offers yet more support to the case for an FTA. Interestingly, Canada would not have met the original criteria set out by the EU for potential FTA partners, focused as they were on emerging economies with 
significant growth potential and major barriers to EU trade. The inclusion of Canada (and subsequently Japan and the USA) therefore signals an important shift in the EU's willingness to conduct bilateral agreements with developed economies.

\section{Now CETA could provide us with a useful roadmap}

Indeed, as Don Kenyon and Pierre van der Eng (2014a) point out, CETA could serve as a template or road map for a possible Australia-EU deal. For a start, there are clearly some close parallels between the Australian and Canadian economies. This suggests that much of the logic that made Canada an attractive negotiating partner for the EU should likewise apply to Australia. In addition, Australia's geographic proximity and deep integration with Asian economies is an added advantage.

More particularly, however, there is the nature of CETA itself, with its focus on removing NTBs to services and investment, and its coverage of issues such as regulatory standards, rules and people movement. So, for example, work by the EU and Canada found that trade in services between the two economies was subject to significant barriers that were estimated to increase the cost of service provision by between 20 and 50 per cent. An official joint study drew on this kind of evidence to conclude that bilateral trade could be increased by between 20 and 25 per cent in both directions if a comprehensive deal were reached, with roughly half of the effect coming from liberalisation of trade in services, and roughly onequarter each attributable to reductions in tariffs and in technical barriers. ${ }^{10}$

The relative importance of services trade and investment in the CanadaEU bilateral relationship worked to encourage a focus on the importance of behind-the-border issues (Schwanen 2011). Given the similar importance of services trade and investment in the Australia-EU relationship as set out above-remember, the EU is our most important services trade partner, our largest foreign investor and our second-most important investment destination-progress in these same areas would offer the potential for significant economic gains. For example, as Kenyon and van der Eng (2014b) have emphasised in their work, large benefits

10 These figures also assumed that the Doha Round would be completed. If Doha was not completed, the estimated gains would likely be significantly greater (Deutsch 2012). 
for business could be realised by the mutual recognition of technically divergent but functionally broadly equivalent licensing, labelling, standards, certification regulations and professional qualifications.

From an Australian perspective, the striking thing about CETA is that it is the most ambitious services trade agreement that the EU has negotiated to date, with commitments that are better than those offered in the EU's FTA with Korea and that are also superior to current EU offers in the ongoing TiSA negotiations. Notably, CETA marks the first time that the EU has adopted a 'negative list' approach in an FTA, which combines commitments that bind current market access with future liberalisation except where reservations are listed. Since this is also the approach to services liberalisation favoured by Australia, CETA represents a positive signal that a relatively liberal and dynamic outcome is possible.

Another important feature of CETA is the inclusion of an MFN obligation to extend any future preferential treatment (except in relation to the EU's own internal market or the European Economic Area), which helps 'future-proof' the deal. Canada was also successful in using CETA to persuade Brussels to reduce the number of policy space reservations across a range of sectors, including professional services, environmental services, transport services and other business services-all of which would be of great interest to Australia. The CETA provisions relating to financial services would similarly look attractive to any future Australian negotiators.

CETA also suggests that a deal with the EU would offer the opportunity to boost innovation. CETA, for example, not only includes commitments on research and development services, technical testing and analysis and other scientific and technical consulting services, but also establishes a bilateral dialogue on enhanced cooperation on science, technology, research and innovation issues.

\section{Engaging with the new trade policy landscape}

Both the specific example of CETA and the more general trend towards deep integration as exemplified by the ambitious aims of the new megaregional deals reflect the shifting nature of international trade in today's global economy. That trade is increasingly characterised by international 
production networks and global value chains, which in turn are heavily reliant on close connections between services, standards, intellectual property, the role of foreign affiliates, and cross-border flows of capital and labour. As is now well known, many of these variables are most influenced not by traditional, at-the-border policy measures such as tariffs or quotas, but rather by behind-the-border measures including standards and other regulations.

Some optimists now see the FTA route in general and the mega-regional route in particular as potentially contributing to the emergence of a 'multilateral deal through the back alley', producing the kind of agreement that will end up being 'far more liberalising and comprehensive than could ever be attained in Geneva' (Suominen 2012). The argument here tends to be based around the idea of critical mass. That is, a successful TTIP would encompass an economic region that contributes about half of world trade. As a result, if these economies were to agree on a common set of standards or regulations, there will be strong incentives for exporters in the rest of the world to conform to those same standards. Since any trading partner choosing to do so would then see its overall trading costs with both the USA and the EU decline, this would tend to reduce costs (and boost competition) for international players across the board (Cernat 2013). The end-game in this optimistic version of the world would then be the emergence of a set of global rules by a process of gradual accretion.

While the optimism about an effective global agreement may well turn out to be overdone, the potential importance of this kind of effect, as well as some of the risks it entails for the rest of the world, can be seen in some of the modelling around the likely impact of a TTIP on the rest of the world. For example, the main study commissioned by the European Commission on TTIP found that liberalising trade between the EU and the USA would have a positive impact on overall world trade and income. However, it turns out that the impact on the rest of the world is critically dependent on assumptions made about the potential for international convergence on EU-USA standards, which would then become de facto global standards in the way described above. This would produce lower NTBs worldwide and so deliver increased market access 
for third countries that would help offset any trade diversion. ${ }^{11}$ It is these assumptions about reductions in NTBs that ensure economies in the rest of the world see an increase in welfare via a reduction in global trade costs as a result of the TTIP. ${ }^{12}$

The impact of these assumptions is highlighted by the findings of another study of the TTIP — this time by Germany's Bertelsmann Foundationwhich in marked contrast identifies the potential for a significant degree of trade diversion (Felbermayr, Heid \& Lehwald 2013). This report looks at two scenarios for the TTIP, one based on the elimination of tariffs alone, and one based on the kind of deep integration produced by eliminating NTBs. The tariff-only scenario sees the main losers from TTIP-induced trade diversion concentrated in those developing and emerging economies reliant on EU and US export markets-with the biggest losses in North and West Africa. According to this model, Australia is a small loser from trade diversion, suffering a 0.6 per cent fall in real income per capita in the long run. However, the same report's 'deep integration' scenario models a much bigger hit to welfare, with Australia seeing a 7.4 per cent drop in its long-run real per capita income, alongside other big losers including Canada ( -9.5 per cent), Mexico ( -7.2 per cent) and Japan ( -5.9 per cent).

This negative impact is in large part because this study explicitly does not take into account the likelihood that these countries would adopt the same standards and regulations as prevail under a completed TTIP. The study's authors highlight the fact that these results provide a strong argument for countries such as Canada that already have an agreement with one partner in TTIP to conclude another (which the Canadians have just done with CETA). Obviously, the same argument applies to Australia: if the EU and the USA are going to be in effect writing the global rule book, we will likely end up having to adopt it one way or another, or suffer increased

11 The study actually makes two important assumptions here. First, it assumes direct spillovers whereby the bilateral EU-USA streamlining of regulations and standards also provides benefits to third parties, since it will become less costly to meet these new, simplified standards. Second, it also assumes indirect spillovers whereby third markets choose to adopt some of the common standards agreed by the EU and the USA (Francois et al. 2013).

12 A recent study by CEPII also finds 'little trade diversion induced by a TTIP', with additional bilateral trade mostly replacing domestic production. The USA sees some trade diversion from the rest of the world, mostly concentrated in manufacturing, while in the EU there is no trade diversion overall as the trade diversion in agriculture (whereby imports from the USA displace those from third markets) is more than offset by trade creation with third countries, mainly through global value chain effects (Fontagné, Gourdon \& Jean 2013). 
relative trade costs. With that prospect in mind, it makes sense to seek to be an active participant in shaping the rules as far as possible, a proposition that further reinforces the case for an Australia-EU FTA.

As mentioned earlier, Australia remains committed to the multilateral system and the benefits of a comprehensive multilateral round. Australia is mindful of its commitments in FTAs as a way to continue to progress liberalisation, including through inbuilt agendas, to ensure our efforts are not counter to, but support, our efforts globally, to keep the door open for a multilateral round.

\section{Conclusion: The case for an Australia-EU agreement}

In conclusion, then, there are several good reasons for considering the case for an Australia-EU FTA. Some of these are fairly obvious. In particular, the substantial nature of the existing bilateral economic flows, particularly with regard to services trade and investment, are indicative of the scale of potential pay-off from a successful agreement. Likewise, the fact that the EU currently stands out as the 'biggest single missing jigsaw piece' in our existing and prospective network of FTAs supports the logic of a push to negotiate a deal.

Then there is the argument that there are grounds for believing that agriculture may no longer be the deal-breaker that it has been in the past, and indeed that there might now be scope to deliver improved access to the EU's high-value internal market for Australian farmers. There may also be important opportunities for Australian businesses to cooperate with European agri-supply chain operations to leverage Australia's role as a 'gateway to Asia'. On top of this, the limited opportunities currently on offer via the multilateral route, along with a sluggish global growth environment and some signs of increased protectionist pressures across the world economy, argue for valuing the general growth and liberalisation benefits on offer from pursuing a bilateral agreement with the EU.

All of these arguments are given further force by the fact that the EU is already negotiating deals with many of our key regional trading partners, as well as a prospective 'mega-regional' deal with the USA in the form of a TTIP. Since the latter in particular has the potential to set the rules of the global game across a range of issues, it would be advantageous for 
Australia to maximise our input into the process and minimise the risks associated with trade diversion. Further, the EU is seemingly willing to embark on a negotiating approach compatible with Australia's significant interests.

It seems probable that an FTA with the EU would also offer Australia additional pay-offs. For example, as Jim Rollo pointed out in 2011, there would be potentially important pay-offs for Australia's exports of elaborately transformed manufactures through the reduced trade costs that could come from the mutual recognition of regulatory regimes (Rollo 2011). Similarly, there could be gains from improved deals on the movement of people, and from enhanced access to government procurement markets across the EU. There could also be significant payoffs for domestic policies within Australia. For example, Adams, Brown and Wickes (2013) have suggested that the sort of major FTA that a deal with the EU would entail could also serve as a useful spur for domestic reform efforts.

Finally, joint work together in recent years-including on Doha-has underlined that Australia and the EU do share interests in global economic governance and in encouraging transparency, openness and liberalisation. Surely as Australia engages in mega-deals across regions and with other major economies, it should be working together with the EU to enhance not only bilateral linkages, but also common global interests.

In summary, then, there is, at minimum, a strong case from an Australian perspective to consider carefully the merits of pursuing an FTA with the EU.

\section{References}

Adams, Mike, Nicolas Brown \& Ron Wickes (2013), Trading Nation: Advancing Australia's Interests in World Markets (UNSW Press: Sydney).

ABS (Australian Bureau of Statistics) (2015), 'International Investment Position, Australia: Supplementary Statistics, 2014. Cat No. 5352.0', Australian Bureau of Statistics, May.

Austrade (2012), Australia-Europe Brief, Edition 7 (September).

Austrade (2013a), Australia-Europe Brief, Edition 9 (March). 
Austrade (2013b), Australia-Europe Brief, Edition 10 (June).

Cernat, Lucian (2013), 'TPP, TTIP and multilateralism: Stepping stones or oceans apart?', VoxEU.org, 8 November.

Deutsch, Klaus Gunter (2012), Looking for Partners: The EU' Free Trade Agreements in Perspective, EU Monitor (Deutsche Bank Research: Frankfurt am Main), 27 July.

DFAT (Department of Foreign Affairs and Trade) (2014), Composition of Trade Australia 2013-14 (Trade and Advocacy Section, DFAT: Canberra), December.

DFAT (n.d), 'Australia's trade in goods and services 2013-14'. Available at dfat.gov.au/about-us/publications/trade-investment/australias-tradein-goods-and-services/Pages/australias-trade-in-goods-and-services2013-14.aspx.

Evenett, Simon J. (2014), The Global Trade Disorder: The 16th GTA Report (Centre for Economic Policy Research: London).

Felbermayr, Gabriel, Benedikt Heid \& Sybille Lehwald (2013), Transatlantic Trade and Investment Partnership (TTIP): Who Benefits from a Free Trade Deal? (Bertelsmann Stiftung: Gütersloh).

Fontagné, Lionel, Julien Gourdon \& Sébastien Jean (2013), Transatlantic Trade: Whither partnership, which economic consequences? CEPII Policy Brief No. 1 (Centre d'Etudes Prospectives et d'Informations Internationales: Paris), September.

Francois, Joseph, Miriam Manchin, Hanna Norberg, Olga Pindyuk \& Patrick Tomberger (2013), Reducing Transatlantic Barriers to Trade and Investment: An Economic Assessment, Final Project Report (Centre for Economic and Policy Research: London), March.

IMF (International Monetary Fund) (2015a), Uneven Growth: Short and Long Term Factors, World Economic Outlook April 2015 (International Monetary Fund: Washington, DC).

IMF (2015b), World Economic Outlook Database. April 2015 (International Monetary Fund: Washington, DC). 
Kenyon, Don \& Pierre van der Eng (2014a), 'Defining the relationship between Australia and the European Union: Is the framework treaty enough?', Australian Journal of International Affairs 68(2): 225-42.

Kenyon, Don \& Pierre van der Eng (2014b), 'Why isn't Australia negotiating an FTA with the EU?' in The Transatlantic Trade and Investment Partnership: Implications for Australia and the AsiaPacific, ANU Centre for European Studies Briefing Paper, 5 (Canberra: ANU Centre for European Studies), 23-28.

Mortimer, David with John Edwards (2008), Winning in World Markets: Meeting the Competitive Challenge of the New Global Economy: Review of the Export Market Development Grants Scheme (Review of Export Policies and Programs: Canberra), 1 September.

Murray, Philomena \& M. Bruna Zolin (2012), 'Australia and the European Union: Conflict, competition or engagement in agricultural and agri-food trade?', Australian Journal of International Affairs 66(2): 186-205. doi.org/10.1080/10357718.2011.646481.

OECD (Organisation for Economic Co-operation and Development) (2013), FDI in Figures October 2013 (OECD: Paris).

Rollo, Jim (2011), 'The potential for deep integration between Australia and the European Union: What do the trade statistics tell us?', Australian Journal of International Affairs 65(4): 394-409. doi.org/10. 1080/10357718.2011.586321.

Schwanen, Daniel (2011), 'Go big or go home: Priorities for the Canada-EU economic and trade agreement', C.D. Howe Institute Backgrounder, No. 143, October.

Suominen, Kati (2012), 'The surprise endgame in global trade', VoxEU.org, 20 December.

UNCTAD (United Nations Conference on Trade and Development) (2014), World Investment Report 2014: Investing in the SDGs: An Action Plan (United Nations: Geneva).

WTO (World Trade Organization) (2014), International Trade Statistics 2014 (WTO: Geneva). 
AUSTRALIA, THE EUROPEAN UNION AND THE NEW TRADE AGENDA

WTO (2015), World Tariff Profiles 2015 (WTO: Geneva). Available at www.wto.org/english/res_e/publications_e/world_tariff_ profiles15_e.htm.

WTO, OECD \& UNCTAD (2015), Reports on G20 Trade and Investment Measures (mid-October 2014 to mid-May 2015), 15 June. Available at www.oecd.org/daf/inv/investment-policy/13thG20-Report.pdf. 
This text is taken from Australia, the European Union and the New Trade Agenda, edited by Annmarie Elijah, Don Kenyon, Karen Hussey and Pierre van der Eng, published 2017 by ANU Press, The Australian National University, Canberra, Australia. 